Nereida Villagra

\title{
4 Lost in Tradition: Apollodorus and Tragedy-Related Texts
}

\section{Introduction}

Whether Apollodorus consulted his sources directly or through intermediary sources is a subject still under discussion. ${ }^{1}$ It has been argued that Apollodorus depended on tragedy mainly through secondary texts such as hypotheseis. Huys tried to identify the relationship between Apollodorus' Bibliotheca and Euripides and the Tales from Euripides, and concluded that Apollodorus did not quote the tragedies or the Tales at first-hand, but that the set of tragic hypotheseis and the Bibliotheca may sometimes derive from a common source, which he proposed was an Alexandrian scholarly work. ${ }^{2}$

Already in the fourth century there existed other tragedy-related texts, such as the Tragodoumena of Asclepiades of Tragilos which, according to Robert, ${ }^{3}$ were consulted by Apollodorus directly. The title of this work suggests that it was some

Note: This article was written with the support of a postdoctoral scholarship from the Fundação para a Ciência e a Tecnologia of Portugal, and by the Centro de Estudos Clássicos of the Universidade de Lisboa (SFRH/BPD/90803/2012).

1 Huys 1997, 309-310, n. 6, 8 with bibliography; Kenens 2011, 130-131, n. 1, 2, 3 gives more bibliography. See also Scarpi 1996; Cuartero 2010.

2 Huys writes: "Still, this case proves that the Library contains sequences that go back at least to material used also by the author of the Tales [from Euripides] ... It seems likely, then, that one of these collections of hypotheses was a source of the Library, but it cannot be proved that the mythographer himself excerpted this source. As to the possibility that he would have consulted the text of Euripides, this seems very improbable, and even for the prologues, which might have been included in a collection of hypotheses, the arguments used do not convince me. Apollodorus was indebted, directly or more probably indirectly, perhaps through the intermediary of a mythographic manual, to Alexandrian scholarship, hypotheses and learned commentaries' (1997, 32526). On the tragic hypotheseis and the Tales from Euripides see Wilamowitz-Moellendorf 1875, 182-184; Barret 1965; Zuntz 1955; Rusten 1982; Haslam 1975; Budé 1977; van Rossum-Steenbeek

AQ1 1998; Meccariello 2014.

3 Robert 1873, 55.

Nereida Villagra, Universidade de Lisboa

DOI 10.1515/9783110545326-004

AQ1: Reference Scarpi (1996), Wilamowitz-Moellendorf (1875), Budé (1977) is cited in text but not provided in the list. Please provide complete publication details to insert in the list, else delete the citation from the chapter. 
sort of commentary on tragedies. Since all the fragments are mythographical, ${ }^{4}$ one would expect the Tragodoumena to have dealt with the plots of tragedies, being an antecedent of a sort to the sets of tragedy hypotheseis. ${ }^{5}$ On the other hand, among the scholia to tragic texts, only those to Euripides quote Asclepiades. At the same time, Euripides is the only tragedian quoted by Apollodorus, who, in turn, as we have said above, is thought to have used the Tragodoumena as a source.

Therefore, one wonders if the Tragodoumena could have been the source for certain tragic plots or variants found in the Bibliotheca and how the three works relate to each other. A priori, there is no evidence linking the tragic hypotheseis to the Tragodoumena directly: no preserved hypothesis mentions the name of Asclepiades or his work, nor do Asclepiades' fragments quote specific tragedies or explicitly summarise them, ${ }^{6}$ but this lack of evidence may be due to the current state of both texts.

The objective of this article is to assess the relationship between the Bibliotheca and this secondary tragic narrative tradition, as embodied by both the Tragodoumena and the tragic narrative hypotheseis. Accordingly, Apollodorus' quotations of Asclepiades, of anonymous tragedians and of Euripides will be analysed first. Then I will look for correspondences of subject matter between the three texts - the Bibliotheca, the Tales from Euripides and the Tragodoumena and compare the passages which deal with the same mythical episode. ${ }^{7}$ Finally, I will examine other thematic or detail-related coincidences between other corresponding passages of the Bibliotheca and the Tragodoumena where Apollodorus does not quote Asclepiades.

This approach faces the tremendous burden of the current state of what we are calling the 'tragedy-related' texts. Both the Tragodoumena and the narrative hypotheseis have come down in a fragmentary state. Whereas in the case of the tragic hypotheseis, we do have an original text, though it is discontinuous - not every known tragedy, preserved or not, has its own hypothesis and hypotheseis are often conjectural (i. e., scholars agree that a passage of Apollodorus, Hygin or

4 The fact that they deal with myths can be simply a result of the interest of the source that quotes the passage and the fact that when we edit Asclepiades' fragments we automatically discard those passages which quote the name Asclepiades as an authority for non-mythographical issues. See schol. Pind. Ol. 6.26; Ol. 8.10e, i; Ol. 8.29a.

6 Except, perhaps, for one fragment ( $F G r H$ 12F15), which refers to oi tpayıкoí. See Villagra Hidalgo 2014, 27-41.

7 I am indebted to Huys' article on the relationship between Apollodorus' Bibliotheca and the Tales of Euripides, which is the basis for this work. See Huys 1997.

AQ2: Reference Villagra Hidalgo (2008), is cited in text but not provided in the list. Please provide complete publication details to insert in the list, else delete the citation from the chapter. 
other narrative text conveys the plot of a lost drama $)^{8}$ - the text of the Tragodoumena is not only disjointed but also extremely derivative. ${ }^{9}$ The passages attributed to Asclepiades of Tragilos by indirect tradition have mostly been conveyed by scholia and it is therefore very hard to assess a quotation and its context from an authorial or even work-centred perspective. Also, there is often uncertainty about the attribution of the quotations. Thus, we are actually not dealing with a text, but with a textual artefact, built by editors upon the slippery basis of sources which are themselves also textual artefacts (scholia and lexicographical works). Therefore, no conclusive evidence regarding the sources can be drawn from the comparison proposed here. However, I hope that this article can add something to current knowledge of the frequency of coincidences and divergences between these texts, and also of the different narrative procedures they use, which in turn can throw some light on the pursposes of these works. ${ }^{10}$

\section{Quotations of tragedy-related authors in Apollodorus' Bibliotheca}

As already noted, Carl Robert believed that Apollodorus consulted Asclepiades of Tragilos directly. ${ }^{11}$ However only two citations of the name Asclepiades appear in the Bibliotheca and neither gives the title of the work. This poses an identification problem, since Asclepiades is a very common anthroponym and many authors bore the same names. ${ }^{12}$ The difficulty is accentuated by the fact

8 Rusten 1982, 361, n. 21. See also Huys 1997, 317-18 for bibliographical references.

9 Editions of the Tragodoumena include Werfer 1815; Müller 1849; Jacoby 1923; Villagra Hidalgo 2012; Ashirvatam forthcoming.

10 By 'narrative procedures' I refer to the way a story is told: it can be nothing more than a detail in a catalogue or a divergence in an account, it can be alluded to, or it can be an independent narrative, or an episode within a larger story. On mythography as a literary genre see Alganza Roldán 2006, 9-37, especially 9-13. Higbie 2007 avoids the discussion with the term 'Hellenistic mythographers'. See other descriptions of mythography in Pellizer 1993, 283-303; Fowler 2000, xvii-xxxviii; Fowler 2006, 35-46; Meliadò 2015, 1057-1089; Fowler 2013, xi-xxi.

11 Robert also believed that Apollodorus relied on intermediary authors for the tragedians. See Robert 1873, 55.

12 Besides Asclepiades of Samos, Pauly-Wissowa's Realencyclopädie identifies other 50 different Asclepiades. At least 19 are authors, philosophers, grammarians, poets or historians; eight are doctors. We only have a single testimony for many of them. Epigraphic onomastic studies show the existence of 29 different men with that name in Thracia and 344 in Attica in different periods.

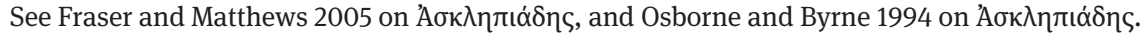

AQ3: Reference Villagra Hidalgo (2012), is cited in text but not provided in the list. Please provide complete publication details to insert in the list, else delete the citation from the chapter. 
that Apollodorus does not stick to a specific genre when quoting sources, but uses epic poets (Hesiod, Homer and other poets of the epic cycle), tragedians (Euripides or unidentified others), logographers and mythographers (Pherecydes, Acusilaus or Asclepiades). ${ }^{13}$ The two passages which quote Asclepiades - if this is indeed the mythographer - use him as a source for very specific details. In the first, Asclepiades' name is quoted along with other authorities for a variant of the parenthood of Argos Panoptes. A few lines before, Apollodorus refers to the father of Io and quotes the tragedians. This passage is at the beginning of the second book, which is devoted to the descendants of Inachos, the argive genealogy. I will comment on these two quotations, for they may be related:

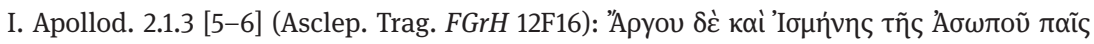

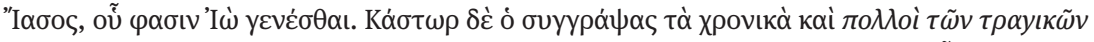

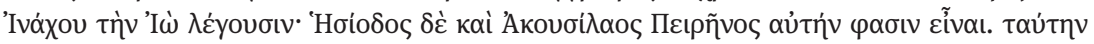

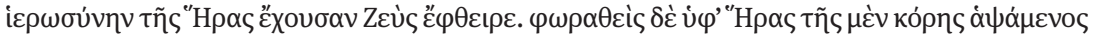

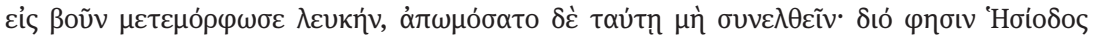

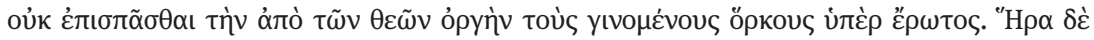

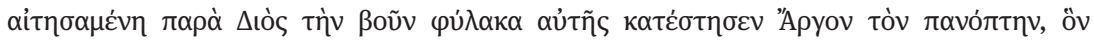

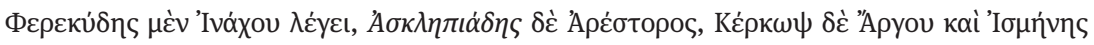

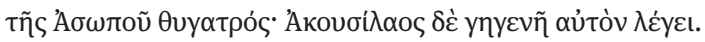

Huys has commented that "the vagueness of the reference to the tragic texts and its insertion in a chain of references make it again very doubtful that Apollodorus would have consulted here the tragic passages themselves: rather he used learned commentaries or previous mythographers'. Huys did not seem to notice that some lines below, when Apollodorus refers to Argos Panoptes' father, he quotes Asclepiades for a variant. If Huys is right about Apollodorus finding the reference to the tragedians in a mythographical source, Asclepiades would be a good candidate for that intermediate text. Indeed, both quotations (the tragedians and Asclepiades) refer to variants of the father of figures who appear in the same plot - the story of Io's transformation into a cow guarded by Argos. We can imagine that Asclepiades' work would have dealt with a tragedy on this popular episode. ${ }^{14}$ Regarding the Bibliotheca's text, most editors accept a correction which

13 Huys 1997, 309, n. 3.

14 Huys pointed out that several fragmentary plays are candidates for the specific reference to Io's father: Aischylos' Prometheus (589), Sophocles' Electra and probably the fragmentary Inachus, Euripides' Supplices or Chaeremon's Io. However, if Asclepiades were really behind the reference to the tragedians, Sophocles' Inachus or Chaeremon's Io would be a better candidate for the source on the fathers of Io and Argos in both variants. 
consists in switching the order of the authorities Pherecydes and Asclepiades. ${ }^{15}$ If we accepted this, Asclepiades would be more problematic as the intermediate source of 'the tragedians', for we would have to explain why or how a certain tragic tradition made Io and Argos Panoptes sister and brother. Respecting the lectio recepta allows the possibility that Asclepiades may be the intermediate source of the anonymous reference.

On the other hand, the reference to Asclepiades is part of a long Zitatennest which illustrates the difficulties that the genealogy of Argos posed. It does not seem likely that Apollodorus would have personally compared Pherecydes, Asclepiades, Cercops and Acusilaus himself for this detail. He would have found it ready to reproduce in his source. Thus, the picture becomes more complicated for this implies that even if Asclepiades were the source of Apollodorus when he quotes the tragedians, it has been mediated through another Mittelquelle and Apollodorus would be quoting the tragedians at third-hand.

The second quotation of Asclepiades identifies him as the only authority for the name of Minos' wife, Creta: ${ }^{16}$

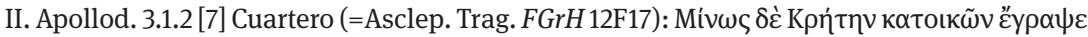

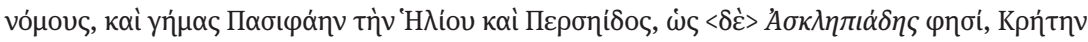

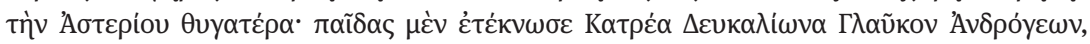

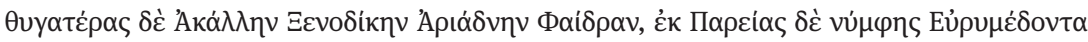

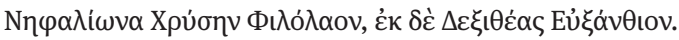

Few lines above this passage, an anonymous source is quoted ('̌vıเ $\left.\lambda \varepsilon^{\prime} y o u \sigma ı\right)$ for a variant of the identity of the object of Sarpedon's and Minos' passion: both brothers fell in love with Atymnius, the son of Zeus and Cassiopeia. ${ }^{17}$ The episode on the quarrel over Atymnius and the note on the name of Minos' wife may come from different sources. However, both narratives relate to the same figure, Minos. Therefore, we cannot exclude the possibility that the $\lambda \dot{\varepsilon}$ you which is mentioned for a variant on the name of Minos' wife (i. e. Asclepiades) even though this episode does not appear in his fragments. It is interesting that an Atymnius appears as the brother of Phineus in a Pherecydean fragment which is transmitted by a scholion to Apollonius Rhodius. In the scholion Asclepiades is also quoted for his agreement with Hesiod and Antimachus in the paternity of Phineus:

15 Cuartero 2012, 23; Fowler 2000, 20.

16 The heroine's eponym is only mentioned by Diod. Sic. 4.77, which considers her to be Pasiphaë's mother.

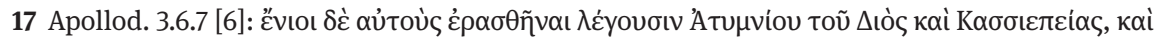

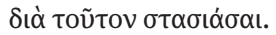

AQ4: Reference Cuartero (2012), is cited in text but not provided in the list. Please provide complete publication details to insert in the list, else delete the citation from the chapter. 
Pherecydes fr. 86 Fowler (=Schol. Ap. Rhod. 178-82a): Ayńvopos yò

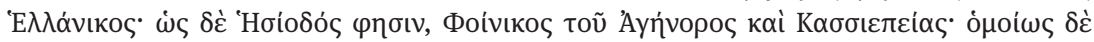

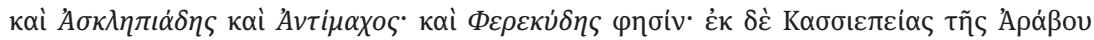

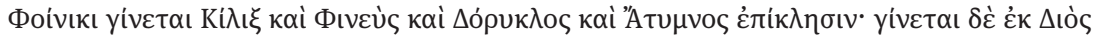
"Aтunvoc. ${ }^{18}$

Perhaps the $\lambda \dot{\varepsilon} y o u \sigma ı$ in Apollodorus' text for the variant on Atymnius' paternity refers also - or exclusively to Pherecydes - without naming him, as he is the one who considers Atymnius a son of Zeus, as we know from the scholion. It is worth noting that according to the scholion to Apollonius, Asclepiades mentioned Cassiopeia and her son Phineus. It would perhaps be going too far to suggest that Asclepiades may have also mentioned Atymnius, another son of Cassiopeia. But the important fact here is that Atymnius is mentioned by Pherecydes in a passage where Asclepiades is also quoted. This suggests that the scholiast to Apollonius Rhodius is using an intermediate source where these two authorities are already mentioned together. Therefore, one wonders if Apollodorus too could have relied on an intermediate source - the same or another - where Pherecydes appeared along with Asclepiades, and quoted this source anonymously first for the quarrel between Minos and his brother, and then quoted Asclepiades by name, because he was already mentioned in the intermediate source for the aberrant version of Creta as Minos' wife. Of course, this is all hypothetical, but the point is that we cannot jump to the conclusion that Asclepiades is being quoted at first-hand for this variant, even though he seems to be the only source quoted here.

Besides the reference to the tragedians already commented upon in connection to Asclepiades, Apollodorus refers twice more to unnamed tragedians. According to Huys, these quotations are not likely to depend on tragic texts either. ${ }^{19}$ One wonders, then, if they may derive from Asclepiades.

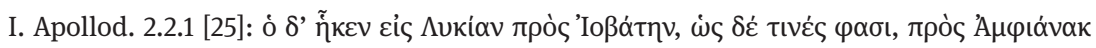

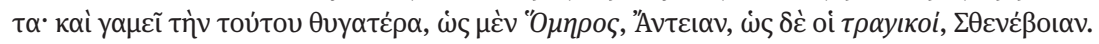

The reference to authorities in this passage can be considered a Zitatennest,

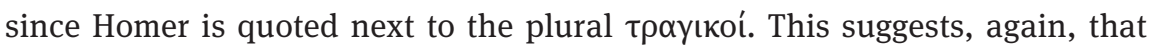
Apollodorus relied on a previous work in which the comparison of different tragic texts had already been done. There is a fragment of this story attributed

18 For the punctuation and attribution of the fragment to Pherecydes see Fowler 2013, 728; Pàmias 2008, 17.

19 Huys 1997, 315-17, n. 31. 
to Asclepiades, conveyed by the Mythographus Homericus ( $\mathrm{MH}$ henceforth). ${ }^{20}$ According to this text, Asclepiades knew Proetus' wife by the name of Antea, which does not match the variant attributed to the tragedians by Apollodorus. However, on the one hand, the MH text quoting Asclepiades is a scholion to the Iliad. Therefore, it is not surprising that the commentator sticks to the name given by the epic tradition. On the other hand, Asclepiades is quoted at the end of the text with a 'blanket reference', a vague way to indicate the source. ${ }^{21}$ Therefore, Asclepiades could refer to another episode or detail in the narrative. The main point is that we cannot assume that the narrative in the scholion to the Iliad reflects the original narrative of Asclepiades. What is significant in this case is that there is a coincidence of subject matter which opens the possibility that Asclepiades' Tragodoumena are actually behind the reference to the tragedians.

The second passage quotes the tragedians for a variant of Nauplius' wife, Clymene:

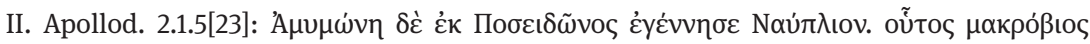

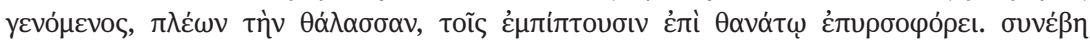

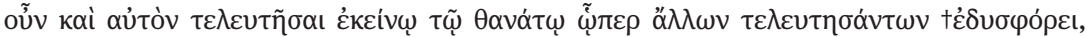

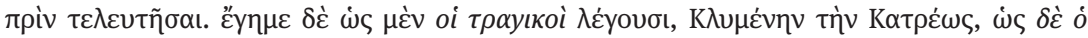

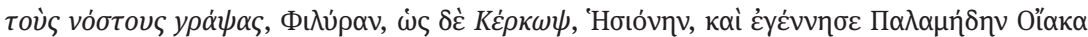

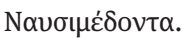

Again, the references are embedded in a multiple quotation. It is therefore likely that Apollodorus is relying on an intermediate source in this case too. None of the fragments of Asclepiades refers to Nauplius, but a Clymene is mentioned in fragment 26. She is, according to 'many' ( $\pi \lambda \varepsilon \tilde{\tau} \sigma \tau o \mathrm{~s}$ ), the mother of Deucalion. However, Clymene is a nomen parlans that means 'the famous' and it looks like a chart-name for different female characters. ${ }^{22}$ Therefore, the connection is very weak here. However, as Huys points out, ${ }^{23}$ Nauplius was a popular character in tragedy: we know of about five tragedies named after the hero, and others dedicated to his son Palamedes.

Besides the tragedians in general, Apollodorus quotes Euripides four times. Huys concludes again that these four quotations are not likely to rely on the

20 FGrH 12F13 (= Schol. Hom. Il. 6.155). See the commentary on plot coincidences below. On the MH see Panzer 1892; Pagès 2007; Montanari 1988; Van Rossum-Steenbeek 1998. See also Pagès in this volume.

21 On the vagueness of mythographical quotations see Cameron 2004, 94, 104, 113-15.

22 See LIMC, s.v. Clymene.

23 Huys 1997, 316. 
tragedian directly. ${ }^{24}$ One of the four quotations deals with topics that are not treated in the fragments of Asclepiades, being part of a cluster of references. ${ }^{25}$ In the other three passages a connection can be made:

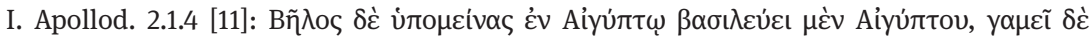

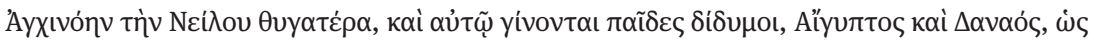

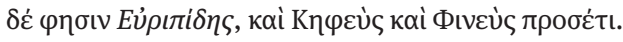

Fragment 31 of Asclepiades - transmitted by a scholion to the Odyssey and considered to belong to the $\mathrm{MH}$ - tells the story of Phineus embedded in a narrative on the Argonauts. Also the scholion to Apollonius Rhodius discussed quoted Asclepiades for Phineus paternity. We thus know that this figure appeared in the Tragodoumena, which opens the possibility that Apollodorus draws on the Tragodoumena here. However, Asclepiades and Euripides are quoted for variants that differ from each other - Phineus is son of Belos in Euripides and son of Phoenix in Asclepiades.

In the third book of the Bibliotheca, Apollodorus lists who killed whom at the siege of Thebes and quotes Euripides for a variant of Parthenopaeus' killer: ${ }^{26}$

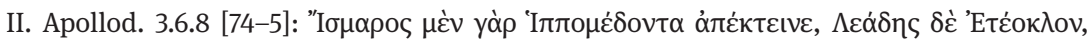

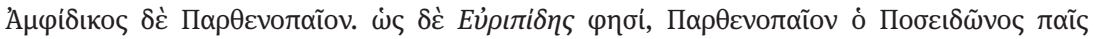

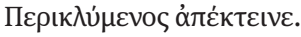

This subject matter is not found in the fragments of Asclepiades, but a Periclymenus is mentioned in fragment 21, which transmits a list of the sons of Neleus and Chloris. ${ }^{27}$ In this fragment, Asclepiades is quoted by the scholia to Apollonius Rhodius for adding Alastor to the list. However, the Periclymenos in this text belongs to a different tradition, unrelated to that on the Theban war, as he is identified as one of the Argonauts. ${ }^{28}$ On the other hand, the Theban war appears in Asclepiades' fragment 29, a scholion transmitted by the scholia to Homer and considered part of the $\mathrm{MH},{ }^{29}$ which tells the episode of how Eriphyle supported

24 Huys 1997, 311-15, 317.

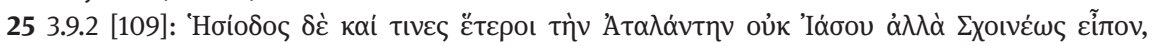

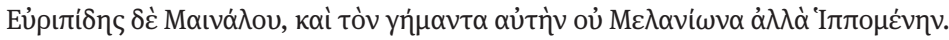

26 Apollodorus' variant is unique. Euripides follows the account in the Thebaid cycle. See Cuartero forthcoming.

27 Schol. Ap. Rhod. 1.156-60b Wendel.

28 In a scholion to Pindar the name Asclepiades is given as an authority for a variant related to this Periclymenos the Argonaut, which says that he was present when Euphemos received a gift from Poseidon. See schol. Pind. Pyth. 4.61.

29 Schol. Hom. Od. 11.326-7. 
Adrastus' decision to fight Thebes against Amphiaraus' advice. However, there is no reference to the development of the war itself. Therefore, once more, there are certain elements which allow us to suggest that the Tragodoumena may be the source of this passage, but the evidence is altogether weak. ${ }^{30}$

The last quotation of Euripides in the Bibliotheca is considered to relate the plot of the lost play Alcmaeon's in Corinth:

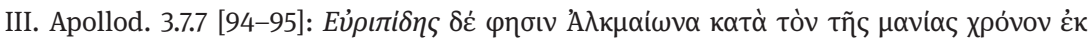

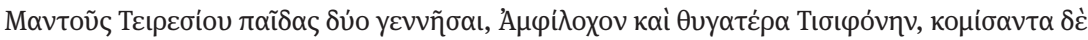

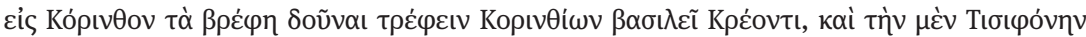

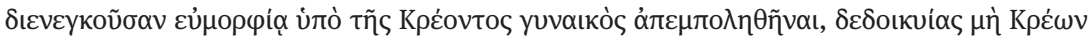

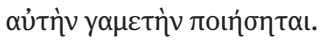

Alcmaeon's madness is briefly refered in Asclepiades' fragment 29, but this subsequent plot is not mentioned. Asclepiades' passage is a condensed iotopí $\alpha$ from the scholia to the Odyssey (i. e. the $\mathrm{MH}$ ) on the quarrel between Amphiaraus and Adrastus and Eryphile, and its consequences for Alcmaeon, who ended up killing his own mother. ${ }^{31}$ In this text Apollodorus only aludes to Alcmaeon's madness. He refers to the matricide and Alcmaeon's purification by the King of Psophis several chapters before the quotation above. ${ }^{32}$ No authority is quoted for Alcmaeon's madness in the Apollodorean text, nor does its version agree with the one attributed to Asclepiades. According to the latter, the gods were the ones to purify him. Therefore, it does not seem likely that there is a connection to Asclepiades in this

30 Huys (1997, 314-15) points out the striking fact that of the four quotations of Euripides in the Bibliotheca, two - this one and the quotation in 3.9.2 [109] - are connected to the same passage of Euripides' Phoenissae and also connected to the mythographical scholia to Homer. Huys believes that these two quotations come from Hellenistic scholarship.

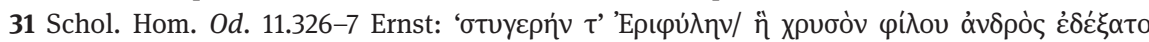

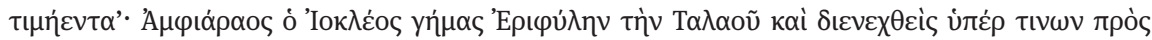

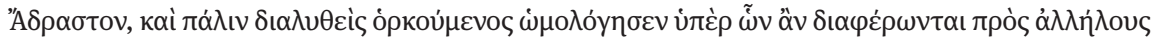

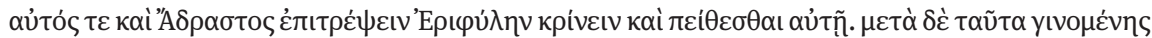

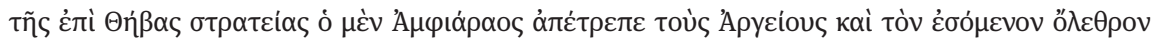

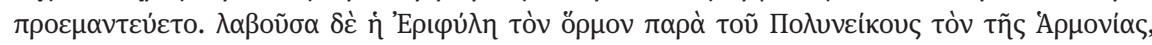

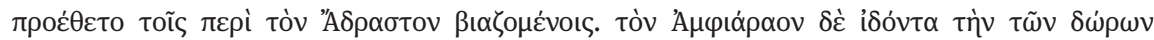

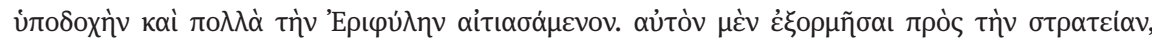

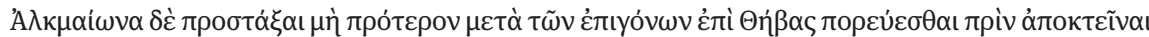

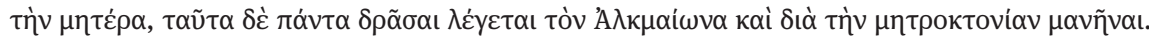

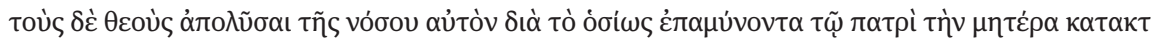

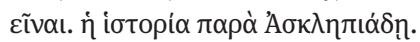

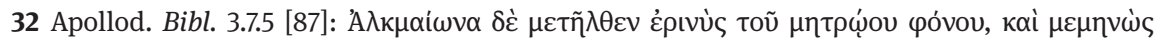

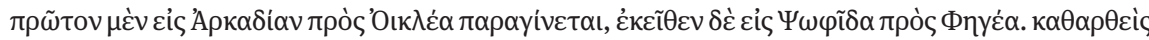

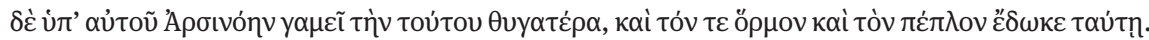


case. If the Apollodorean passage on Alcmaeon's crime and punishment and this quotation of Euripides came from Asclepiades, the Tragodoumena's original text was likely an account which gave both versions of Alcmaeon's punishment, as well as his further destiny at Corinth. Due to the current state of the text, we do not know if Asclepiades compared different versions or quoted other authors, as has been suggested. ${ }^{33}$ The only connection we can establish is again the fact that Apollodorus, Euripides and Asclepiades refer to the same figure, Alcmaeon, and that the three of them refer to his madness, though in different narrative constructions.

I think that before closing this section on quotations, it is worth noting for what purpose and how Apollodorus quotes these authorities. ${ }^{34}$ Both times he quotes Asclepiades, he does so for a specific detail. In the first passage, on Argos Panoptes, Asclepiades is cited among other authorities, each of them for a different variant. Apollodorus himself does not express a preference for any of them. In the second passage, the detail of the name of Mino's wife is a variant to the version which Apollodorus follows and no other authorities are quoted for the same detail.

Apollodorus also quotes unidentified tragedians for specific details and their version is always compared to the epic one. In his quotation of the tragedians on the point of Io's paternity, he quotes them together to contrast their versions with his own variant. In the passage on the name of Proetus' wife, Apollodorus does not align with any version explicitly - although some chapters later, when he tells the story of Bellerophon, he calls Proetus' wife Stheneboea, following the tragic tradition.

Euripides is quoted once for a genealogical variant (the children of Belos), once for a short and condensed episode (Periclimenus killed Parthenopeus) and once for a longer account of Alcmeon, which is thought to summarise the tragedy's plot. In the first two cases, he is quoted to add a variant to Apollodorus' narrative - the detail on Aegyptus' children and the brief episode of

33 See Villagra Hidalgo 2014, 27-41.

34 Regarding Apollodorus' purpose, by 'specific detail' I mean that the variant gives the identity or name of a specific character. If the variant implies some kind of action of a mythical figure, I consider it a brief episode. When I say 'episode', I refer to an event which is integrated into a fuller account. By 'account' I mean a narrative with a sequence of episodes. Regarding how Apollodorus uses an authority, I focus on whether the authority is quoted alone (in order to establish contrast with Apollodorus' preferred version) or if it is presented as an addition to his narrative. I also assess whether an authority is quoted along with other authorities, or the authority assumes the main narrative voice. 
Parthenopaeus' death. However, in the last example Apollodorus lends Euripides the authorial voice.

This points to two ideas: Apollodorus does not always use authorities in the same way. Sometimes he quotes Asclepiades and the tragedians for details which establish contrasts or add variants, or he simply identifies discrepancies. Euripides is used to add details or short episodes to Apollodorus' narrative or to establish contrasts with other versions - in the same way as Asclepiades and the tragedians - but he is the only source quoted for a full account. Of course, the number of these quotations is so small that this may not be significant enough to establish a pattern in the relationship between the quoted authority and its purpose. Nevertheless, we should keep in mind that these are all the tragedyrelated quotations in the Bibliotheca.

\section{Apollodorus, the Tales from Euripides and the Tragodoumena of Asclepiades of Tragilos}

In his article on the Tales from Euripides and the Bibliotheca, Huys listed the passages of the Bibliotheca which have parallels in Euripidean tragic hypotheseis. ${ }^{35}$ When the two are compared to Asclepiades' fragments, it turns out that among the 22 plot coincidences between Apollodorus and the Tales, five topics are also treated by the Tragodoumena. Taking into account the fact that the Tragodoumena were a six-book work from which we only have 32 fragments - according to Jacoby's edition - this does not seem to be an insignificant coincidence. However, one must bear in mind that thematic concurrence does not in itself prove a connection between the texts. The coincidences are the following:

\section{Alcestis (Apollod. 1.9.15 [105-106], hyp. E. Alc., FGrH 12F9)}

The narratives on the death of Alcestis for her husband Admetus have a similar structure in the Bibliotheca and the tragic hypothesis: both refer first to Apollo's demand to the Moerae and the deal they offer; both also explain that no one was willing to die for Admetus, not even his parents, how Alcestis volunteered to do so

35 Huys established two groups of parallels: the first is between the Bibliotheca and preserved hypotheseis and the second between the Bibliotheca and lost hypotheseis. I only consider the parallels with preserved hypotheseis here. 
and how she was saved. However, major divergences can be found in the choice of variants: first of all, Apollodorus' text includes the punishment sent by Artemis, presenting it as a consequence of the fact that Admetus and Alcestis forgot her when sacrificing to the gods at their wedding. This episode is only known through Apollodorus; it is mentioned neither in Euripides' tragedy nor in the hypothesis. The combination of the two accounts is rather abrupt in the Bibliotheca, as Apollodorus seems to suggest that when Apollo talked to Artemis in order to calm her wrath, he somehow ended up obtaining an extension of the king's life from the Moerae, if somebody died in his place. The hypothesis does not explain why Apollo requested such a favour from the Moerae. A second important difference is that, according to the hypothesis, Alcestis was saved by Heracles, whereas Apollodorus is cautious and gives two versions: either Core sent Alcestis back to the world of the living or Heracles brought her back. Therefore, as Huys pointed out, Apollodorus cannot have relied only on the tale from Euripides, at least on the text as it has come down to us.

Fragment 9 of Asclepiades is transmitted by a scholion to Euripides' tragedy. It does not refer to this same episode, but to the previous scene, the one which brings Apollo to Admetus' palace:

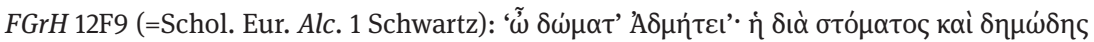

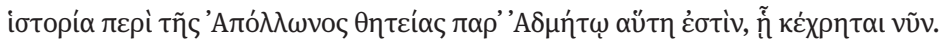

The scholion comments on the prologue of the tragedy, where Apollo explains the antecedents which led to the situation represented in the first scene (i.e. Alcestis is about to die): Apollo had killed the Cyclopes to get revenge on Zeus, who had killed his son Asclepius. Zeus punished him with a year of servitude in Admetus' palace. The scholiast specifies that Euripides follows the common version $\pi \varepsilon \rho і$ iñ s 'А with Hesiod and Asclepiades. We thus infer that Asclepiades gave an account of Apollo's service at Admetus' palace. He may have considered it to be the reason why Apollo asked for Admetus' life to be extended and he may have related the whole story of Alcestis, but this is only conjecture. The fact that the episode of Apollo's service is not mentioned by the hypothesis or by Apollodorus suggests that there is no relation with Asclepiades' fragment. It is also possible that those accounts are different traditions artificially combined by Euripides.

Nevertheless, there is a connection that might be taken into account. The

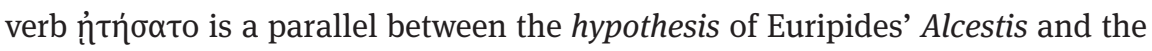
corresponding passage of the Bibliotheca:

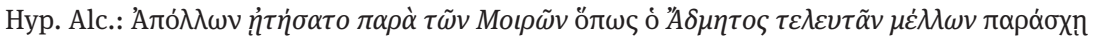

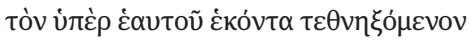




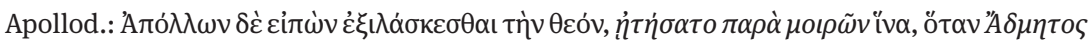

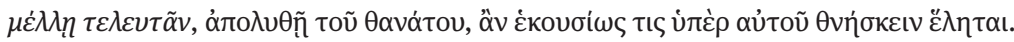

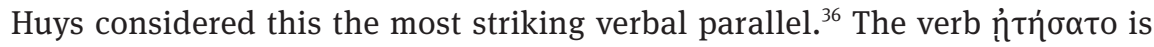
also used by a scholion to Euripides' Alcestis which comments on how the Moerae were convinced by Apollo. ${ }^{37}$ The scholion is transmitted by two Laurentiani manuscripts and provides a brief account which draws on an anonymous source and combines two motifs, the begging - which we find only in Apollodorus and the hypothesis - and the use of wine, already mentioned by Aeschylus: ${ }^{38}$

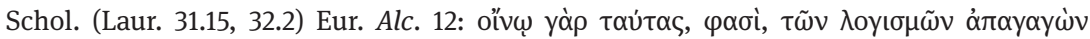

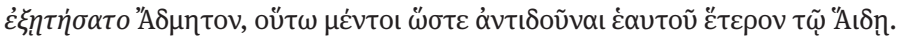

Another scholion, the one to verse 12 of Manuscript A of Euripides' Alcestis, refers only to the wine trick version, pointing out that this goes back to Aeschylus' Eumenides and quoting several verses ${ }^{39}$ One wonders, therefore, if the scholiasts of this manuscript and of the Laurentiani relied on the tragedy itself or on an intermediate source. Since the scholion in the Laurentiani refers to an anonymous source and gives a version which conflates the two details, it seems preferable, for this scholiast at least, to imagine an intermediary source such as the Tragodoumena. If this were so, then the verbal parallel would be a link between the three texts. However, this possibility remains speculative.

\section{Stheneboea (Apollod. 2.3.1 [30-33], hyp. E. Stheneb., FGrH 12F13 [Schol. Hom. Il. 6.155 van Thiel])}

The account of Stheneboea's passion for Bellerophon and its consequences is to be found in all three texts and in this case we do have an attribution to Asclepiades. It has been preserved in a passage of the scholia to the Iliad and it is considered to

36 Huys 1997, 325.

37 Huys 1997, 322.

38 Aesch. Eum. 723-8.

39 I am following Schwartz's sigla: A = Vaticanus 909, c. thirteenth century. The scholion is:

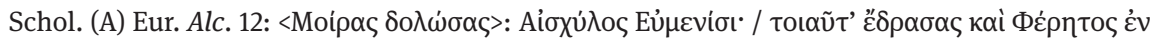

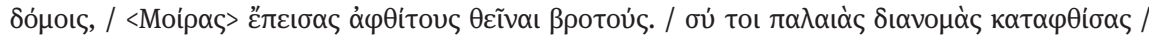
oi̋v 
belong to the $\mathrm{MH} .{ }^{40}$ The tragic hypothesis has been transmitted only by a papyrus and is considered to belong to the Tales of Euripides. ${ }^{41}$

The three versions agree in the first part of the account, the passion of Proetus' wife for Bellerophon and its consequences. The wording differs but the sequence of episodes is the same: Bellerophon's crime and arrival at Proetus' palace; Proetus' wife's passion for him and her inappropriate proposal; Bellerophon's rejection; the wife's lie; the second exile of Bellerophon at Iobates' court; Iobates' trick to avoid killing Bellerophon personally. However, the proximity to the account conveyed by the Iliad suggests that this structure may have been well established since the Homeric text and is thus traditional..$^{42}$ This coincidence does not necessarily imply a common intermediate source, but the common source or hypotext can easily be Homer.

After the account of Bellerophon's journey to Iobates, the three texts diverge: Apollodorus explains all the hero's deeds in detail, and makes him Iobates' successor through marriage to his daughter. He does not refer to the hero's destiny after his marriage and inheritance of the kingdom. The hypothesis refers briefly to Bellerophon's fight against the Chimaera and then gives a completely different version of his final destiny: he goes back to Proetus' court and takes revenge on him by killing his wife, Stheneboea. This is the plot of Euripides' lost play. ${ }^{43}$ The MH's Asclepiades offers a vague reference to Bellerophon's deeds - he does not even mention the Chimaera - and goes on to explain, as Apollodorus and Homer do, that Bellerophon married Proetus' daughter, received a part of his kingdom, and was finally punished by the gods, who made him fall from Pegasos and left him to wander crippled around the Plain of Alia.

Therefore, the coincidences between Apollodorus and the MH's Asclepiades can be explained by their dependence on Homer. However, it is interesting that the Asclepiadean fragment gives details on Bellerophon's punishment which are not present in the Iliad, which only alludes to it. ${ }^{44}$ Had Apollodorus consulted

40 The text has been transmitted in two different recensions in the scholia to Homer and a third in the scholia to Lycophron's Alexandra. Both recensions in the scholia to Homer attribute the account to Asclepiades of Tragilos by a subscription, but they present divergences of detail. It is not possible to know whether the variations were introduced by copyists in the transmission process or if all divergent details belonged to the original text and choices were made by the various scholars who summarised it. See Villagra Hidalgo 2010.

41 POxy. 2455 (see. E. Turner 1962, frs. 5.7-21, 24-95 and 6.1-9) + P. Strasbourg 2676 (see Schwartz 1969). Cf. van Rossum-Steenbeek 1998, 209-211; Diggle 1998, 128-129.

42 Hom. Il. 6.160-202.

43 TGF 5.2, 645-656.

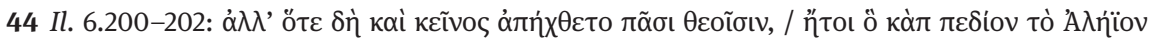

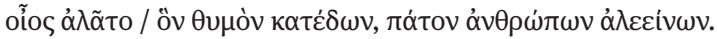

AQ5: Reference Diggle (1998), is cited in text but not provided in the list. Please provide complete publication details to insert in the list, else delete the citation from the chapter. 
Asclepiades, the Tragodoumena account must have been much more complete than the one we have. This is plausible, since the text we have is a scholion which is thought to transmit MH's summary or refection of it. However, even when Apollodorus and the MH's Asclepiades relate the same episode or refer to the same mythological figure, the details diverge. For instance, as we saw above, Apollodorus names Proetus' wife Stheneboea, whereas the MH's Asclepiades calls her Antea, following the epic tradition; according to the Bibliotheca, Iobates' daughter is called Philonoe, whereas for Asclepiades her name is Cassandra; finally, in Apollodorus' text, Bellerophon inherits the kingdom after Iobates' death but in Asclepiades he receives a part of it from the living Iobates. Also, both refer to Pegasos' origins, but in different contexts. Must we imagine that both Apollodorus and the MH draw directly on Asclepiades, who included all these variants, and each author chose different versions? Why then would Apollodorus not have pointed out the existence of divergent versions even once, though he identifies different versions in the same account when he refers to the Chimaera? ${ }^{45}$ It seems unlikely that both the MH and Apollodorus derive from the Tragodoumena. If they drew from it at certain points, they certainly used other divergent sources as well.

The hypothesis cannot depend on the Tragodoumena fragment either, for the two versions are very different. On the other hand, the hypothesis and Apollodorus' text might be considered closer to each other due to the fact that both give the name Stheneboea to Proetus' wife, while Asclepiades calls her Antea (see above). A minor verbal parallel can be found between the hypothesis and Apollodorus:

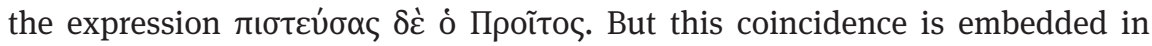
completely different contexts, and is therefore not enough to prove dependence. The Tales from Euripides probably relates the plot of his Bellerophon but, since we only know the tragedy from fragments, we cannot be sure how much in the hypothesis comes from the play and how much comes from a different source.

\section{Heracles (Apollod. 2.4.12 [72]; Hyp. E. Her.; FGrH 12F27)}

The account of Heracles' madness is also transmitted by all three texts. Again, Asclepiades' text belongs to the $\mathrm{MH}$ - this time a scholion to the Odyssey whereas the hypothesis, which is incomplete, has been transmitted only by the manuscript tradition of the tragedy, which has no scholia for this play.

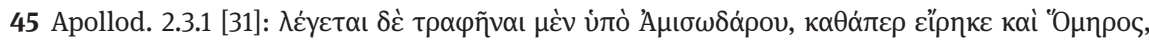

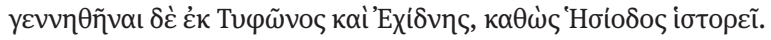


Apollodorus' version of Heracles' madness and killing of his own children an episode explaines in a very summarily way - is placed before the labours. The surviving part of the hypothesis refers the antecedents to the tragedy's plot, which are also explained in the prologue of the tragedy itself. Here, the madness episode takes place after the last labour, the capture of Cerberus, ${ }^{46}$ as it does in Asclepiades' fragment. Apollodorus' account thus differs profoundly from the other two. There is only a partial coincidence between his text and Asclepiades: both mention Iphicles, but the details differ: in the Bibliotheca, Heracles kills his brother's two sons; in the Tragodoumena, he almost kills Iphicles himself. Apollodorus, thus, cannot have depended on the MH's Asclepiades. Had he relied on Asclepiades' Tragodoumena, again, one would expect his account to include all variants and it would therefore be very different from what we have in the scholia to the Odyssey.

As already noted, the hypothesis does not refer to the episode of Heracles' madness, but only to its antecedents. Its version matches that of Asclepiades: both place it after the final labour; both refer to Heracles' marriage to Megara and name Lycus as the ruler of Thebes. All these details already appear in Euripides' tragedy. Therefore, both the hypothesis and Asclepiades (or the MH's Asclepiades) may have depended on the tragic text. However, some details in the MH's fragment diverge from Euripides: first, it gives the names of Heracles' children, which are never mentioned in the tragedy. Secondly, Heracles kills Lycus, his children and his own children, and then almost kills his brother, whereas Euripides has Heracles kill Lycus, his own children and wife, and then he kills almost his father. ${ }^{47}$ The hypothesis agrees with Euripides' prologue in general. The only divergence between them is that the hypothesis has the Thebans revolt against Creon and install Lycus as ruler, whereas Euripides refers to Lycus as having killed Cadmus. ${ }^{48}$

Therefore, it is possible that the hypothesis used some other source, perhaps Asclepiades, though this does not seem probable as the account attributed to him does not mention how Lycus obtained power. It is not possible that Euripides' tragedy is the only hypotext for the MH's Asclepiades or the hypothesis. The MH author either conflated different versions himself or Asclepiades did. However, again, we cannot prove that the hypothesis and the MH used Asclepiades, nor can we rule out that Apollodorus did, although this seems much less likely.

46 Euripides is believed to have altered the traditional episode sequence. See Bond 1981, xxviii-xxx. See also Frade (forthcoming).

47 Apollodorus also presents a different version: according to his account, Heracles kills his own children and his brother's sons by throwing them in the fire.

48 The MH's Asclepiades fragment does not say how Lycus took power. 


\section{The Riddle of the Sphinx (Apollod. 3.5.8 [52-54]; hyp. E. Ph. e + schol. Eur. Phoen. 50 (MVC); FGrH 12F7 [Ath. 10.456B + Schol. Eur. Phoen. 45])}

The subject matter of Euripides' Phoenissae is treated by several passages of the third book of the Bibliotheca. Apollodorus' version of the myth is a very long narrative which expands upon several characters and details drawn from various accounts, ${ }^{49}$ whereas the hypothesis offers a compact summary of the antecedents which led to the Theban war and its consequences for the Theban royal family. The texts' narrative structure and wording are so different that no parallelism can be established between them. The episode of the Sphinx is an antecedent of the story told in the Phoenissae and is referred to in some choral parts of the play where the background of the Theban royal family is remembered. ${ }^{50}$ On the other hand, a large part of the manuscript tradition of the tragedy conveys a poetic version of the riddle the Sphinx posed to Oedipus, which is placed together with the two hypotheseis preceding the tragic text. The same riddle is transmitted in the scholion to verse 50 of the tragedy (manuscripts MVC [Diggle]). Manuscripts BFG (Diggle) quote Asclepiades when giving the riddle before the tragic text. In MVC he is quoted again in the scholion to verse 50. Athenaeus also transmits the same riddle and quotes Asclepiades..$^{51}$ An Oxyrhynchus papyrus which contains part of the prologue to Euripides' Oedipus gives a different version of the enigma, also metric, but does not quote Asclepiades. ${ }^{52}$ The divergence between these two metric versions ${ }^{53}$ points to the possibility that the version in the scholia to Euripides and Athenaeus does indeed come from Asclepiades. ${ }^{54}$ Apollodorus also gives a short prose version of the riddle. Is it possible that he followed Asclepiades as well? His reduced version does not contradict the metric text.

On the other hand, the Asclepiadean fragment has two parts: the riddle and a quotation conveyed by the scholion to verse 45 of Phoenissae, which refers to the killing of the Sphinx at Thebes. If we compare this scholion to the Bibliotheca, new coincidences can be found between Apollodorus and the fragment: both tell that the Thebans gathered together to discuss the riddle, that there was an oracle

49 Apollod. Bibl. 3.5.7-3.6.1 [48-58].

50 Eur. Phoen. 1019-1054.

51 The metric version has also been transmitted by schsol. Eur. Phoen. 50; Anth. Graec. 14.64; arg. 3 Soph. OT; schol. Lyc. 7 Leone, Tz. Lycoph. 7.

52 POxy. 2459 fr. 2. See Turner 1962; TGF 5.1 F540a, p. 572-73. See also Jouan-Van Looy 2000, 449. 53 Also preserved in Athenaios, in the scholia to Sophocles and Lycophron.

54 Asclepiades is likely to have known the riddle through the oral tradition. See Mastronarde 1994, 20, n. 3; Katz 2005, 10, n. 14. 
which declared that the Sphinx would stop killing when its riddle was solved, and that the Sphinx killed many Thebans including Haemon, Creon's son. ${ }^{55}$ The wording is different, but the common details and the riddle suggest that Apollodorus relies on Asclepiades here, though there is no way no prove a direct dependence. It has been argued that Apollodorus depends directly on Euripides for this passage, ${ }^{56}$ but the tragedy does not reproduce the metric riddle.

To sum up, it is likely that both Apollodorus and the scholia on the tragedy drew on the Tragodoumena for the riddle, whereas the papyrus seems to follow a different tradition. Other details in Apollodorus' account may also depend on Asclepiades.

\section{Hippolytus and Phaedra (Apollod. Epit. 1.17-19; hyp. $1 \mathrm{E}$. Hypp.; FGrH 12F29 [schol. Hom. Od.11.321b Ernst])}

Apollodorus' account of Phaedra's passion is only preserved in the Epitome and we cannot therefore know which was its original form. However, the two recensions are very similar in this part. The tragic hypothesis has come down in the manuscripts M, B, O, A, V, C, D, E, P, $\Sigma^{\mathrm{d}}$ (Diggle) of Euripides' Hippolytus, and Asclepiades' account is again conveyed by the $\mathrm{MH}$.

The structure of the narrative of Phaedra's passion for Hippolytus is closer in Apollodorus and Asclepiades. Both follow the Putifar motif and the general structure of the account is the same: Theseus has a son, Hippolytus, by an Amazon and then marries Phaedra. She falls in love with Hippolytus and asks him to sleep with her. He rejects her and she falsely accuses him of having raped her. Theseus believes his wife and asks Poseidon to destroy his son. Hippolytus dies when practising with the chariot. When Phaedra finds out, she commits suicide. However, Apollodorus' account expands upon certain details which the MH's Asclepiades fragment does not mention, and vice versa. Before mentioning that Phaedra falls in love with Hippolytus, the Epitome tells that Phaedra gave Theseus two sons, Acamas and Demophon. One of the recensions of the Epitome also states that when Hippolytus' mother learned of Theseus' wedding to Phaedra, all the Amazons showed up armed at the wedding and there was a fight, in which Hippolytus' mother was killed, some sources say by Theseus. The MH's fragment of Asclepiades gives the following details and expansions not found in Apollodorus: after mentioning the marriage with Phaedra, Asclepiades explains why

55 He is called Menoiceus in the hypothesis.

56 Schwartz 1881, 450ss.; Robert 1915, 544-46; Bethe 1887, 85-86, in Huys 1997, 310, n. 7. plete publication details to insert in the list, else delete the citation from the chapter. 
Hippolytus was in Troezen and locates the episode of Phaedra's falling in love there; Asclepiades then provides information on a temple founded by Phaedra in Athens called the Hippolyteion. ${ }^{57}$ When it refers to Theseus' demand to Poseidon to destroy Hippolytus, the MH's Asclepiades refers to a tradition in which Theseus had been granted three wishes by the god.

The wording is similar at two points: at the beginning of the account, and on Theseus' reaction to Phaedra's false accusation:

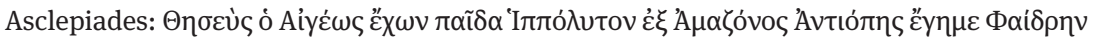

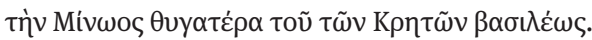

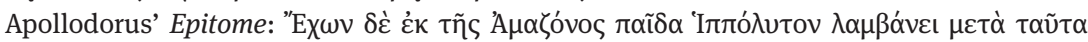

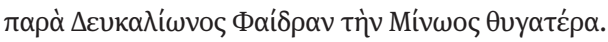

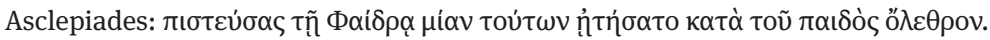

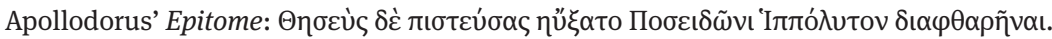

However, these two parallelisms are embedded in narratives that are largely different. Furthermore, the first coincidence is the genealogy, but genealogical information is related in a very repetitive way most of the time. The second regards

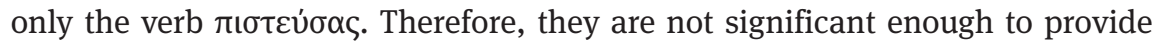
evidence of common dependence.

The hypothesis differs from the other texts both in episode structure and wording. It follows the Euripidean version of the myth in all the details that are put forward in the prologue by Aphrodite. Only the identity of Hippolytus' mother - that she is Hippolyte - is not found in the tragic prologue.

Therefore, in this case, Apollodorus' and Asclepiades' accounts are closer because they follow the same general version, but not close enough to establish a direct relation, whereas the hypothesis follows the Euripidean version. ${ }^{58}$

To sum up: thus far, only in one case is there evidence that suggests that Asclepiades' Tragodoumena was the common source of Apollodorus and the Tales from Euripides: the riddle of the Sphinx. Elsewhere, when Apollodorus and Asclepiades agree, the hypothesis follows a different tradition and vice versa; when Asclepiades and the Tales from Euripides coincide, Apollodorus diverges, and when it is possible that Apollodorus and the hypothesis are linked, Asclepiades cannot.

However, this comparison brings up two points worth noting: first, that the Tragodoumena seems to follow a tradition which is independent to that in the Tales from Euripides (and in Euripides) and, second, that of five thematic

57 On the cult dedicated to Hippolytos see Barret 1964, 3-6.

58 The Euripidean version is thought to be an innovation. See Barret 1964, 1-15. 
coincidences between Apollodorus and Asclepiades, four cases are conveyed by the $\mathrm{MH}$. It has been pointed out that Apollodorus cannot have relied directly on the $\mathrm{MH},{ }^{59}$ which begs the question of the relationship of those two works to the Tragodoumena. It is not possible to assess whether they both rely on the original work or not. Nevertheless, it is worth studying other coincidences between Apollodorus and Asclepiades, independently from the tragic hypotheseis, and to check whether the MH is significant in their relationship.

One final observation for this section: coincidences of detail are dispersed and not very frequent. On the other hand, the similarities that can be established concern subject matter and often narrative structure, too. Neither of these two elements proves a direct relation, but they do show a similar attitude to a specific tradition. The fact that most of the coincidences with Asclepiades' are conveyed by the $\mathrm{MH}$ has a bearing on Asclepiades' perception, as the structure of the account in the $\mathrm{MH}$ is most probably not the same as in the original Tragodoumena, as can be inferred from the fact that every time the MH quotes a mythographer, it presents his account in a similar structure. In my opinion, it is significant that there are structural similarities between Asclepiades' MH and Apollodorus, or between the $\mathrm{MH}$ and the Tales from Euripides, even though there are no parallels of narrative structure between the three texts - besides that regarding Stheneboea. Indeed, these similarities in mythographical procedure support the idea that the three mythographical works belong to a similar cultural ambience.

\section{Parallels between Apollodorus and the fragments attributed to Asclepiades}

In order to assess the role of the $\mathrm{MH}$ in the relationship between the Bibliotheca and the Tragodoumena, I now consider the parallels between Apollodorus and Asclepiades independently of the tragic tradition. I looked for parallels in a broad sense: common subjects, mentions of the same character and coincidences of detail. The reason to for including all this material is that although matches are very often partial, they are interpretable and therefore need individual assesment.

Of the 23 coincidences which I broadly identified, one is a verbal parallel between the Bibliotheca and the narrative attributed to Asclepiades and another shows some coincidence of wording between the context of Asclepiades' quotation and the Bibliotheca. Indeed, the account of Phineus' advice on how

59 See Pagès 2007. 
to navigate between the Symplegades is explained both by Apollodorus and Asclepiades:

Apollod. 1.9.22 [125]: عĩ்

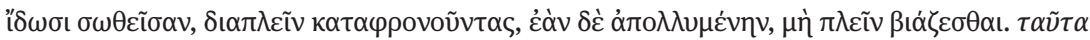

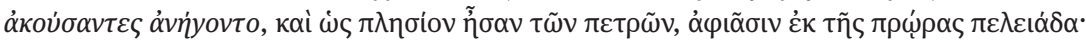

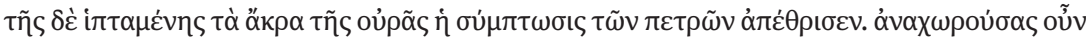

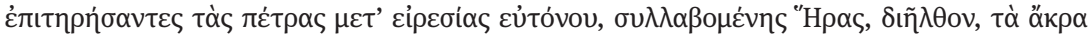

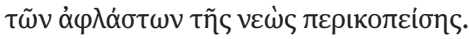

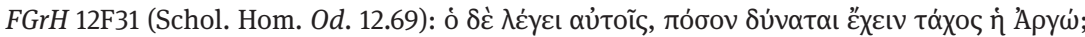

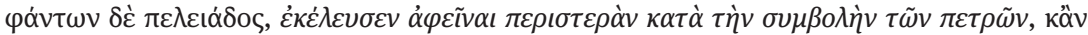

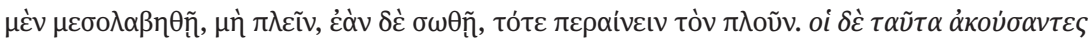

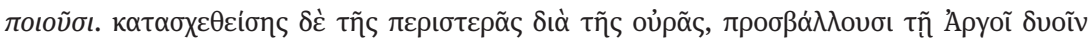

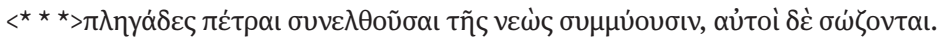

This fragment is conveyed by the $\mathrm{MH}$ one more time. The accounts are clearly parallel, but the coincidences of wording are limited to two sentences, which also show

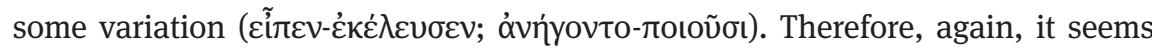
more likely that both texts depend on the same source than one upon the other.

Second, the context of a quotation of Asclepiades transmitted by a scholion to the Odyssey shows some coincidences of wording, but not the text actually attributed to Asclepiades. On the other hand, the parallel concerns only the Prometheus' genealogy and genealogies are generally presented in quite repetitive syntactic schemes:

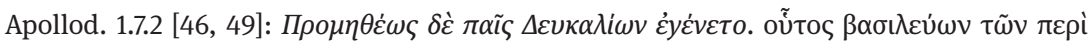

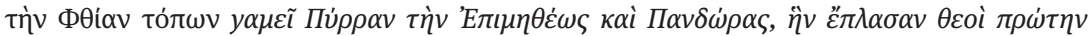

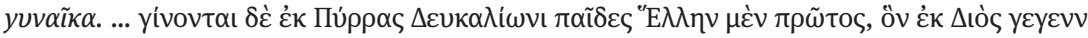

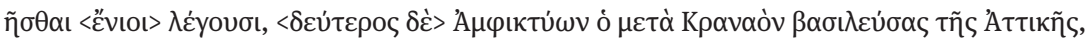

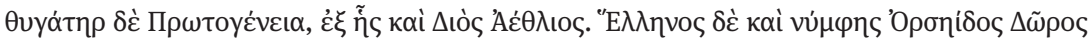

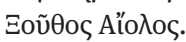

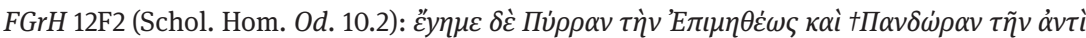

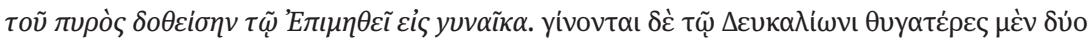

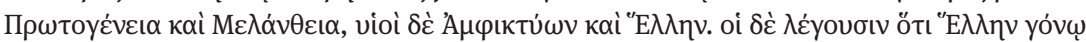

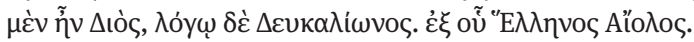

So much for coincidences of wording. Regarding other types of possible connection, there are two accounts - the one on Thamyris and the other on the Lemnian androctony ${ }^{60}$ - which present a similar narrative structure. Nevertheless, wording

60 Thamyris: Apollod. Bibl. 1.3.3 [17], FGrH 12F10 (schol. E. Rh. 916 Merro); Lemnians: Apollod. Bibl. 1.9.17-18 [114-115], FGrH 12F14 (schol. Hom. Il. 7.467 Van Thiel). 
and details diverge. On Thamyris, the following differences can be found: in Apollodorus' version, the musician challenges the Muses because he thinks he is superior, whereas in Asclepiades the competition is set up by the Muses because Thamyris commits the fault of hubris when asking them all to sleep with him because of a Thracian law. In Apollodorus, his final punishment is being deprived of both his eyes and his musical art, whereas Asclepiades only refers to the loss of his eyes. ${ }^{61}$

Regarding the Lemnian episode, in Apollodorus the first mistake in Aphrodite's cult was committed by the women, but Asclepiades says that it was the men's fault. As a punishment, Aphrodite sends a pestilence upon the Lemnian women in Apollodorus, but in the scholion the goddess sends the men a desire for the Thracian women. According to the Bibliotheca, the men take the Thracian women captive and then unite with them, but Asclepiades mentions only their desire. On the other side, he says that the Lemnian women vote to kill the men, a detail omitted by Apollodorus. Hypsipyle saves her father in the Bibliotheca, but not in the Tragodoumena. Both versions report the union with the Argonauts and that between Hypsipyle and Jason, but Apollodorus mentions two sons born of this union and Asclepiades only Euneus.

There are also common episodes in stories which have different narrative structures, but very often, again, the details diverge. For instance, in both texts a short account of Jason's childhood precedes the Argonauts' expedition, but the versions are very different: Apollodorus locates Jason's childhood at Autolycus' court, whereas according to the text attributed to Asclepiades, his mother entrusts him to the centaur Chiron to be raised. ${ }^{62}$

Also in the context of the Argonauts' expedition, the episode of Phineus' punishment and liberation by the Boreads is present in both texts, thus in both cases Phineus' story is embedded in the Argonautic tradition, but the versions diverge. This structural scheme, however, is also to be found in Apollonius Rhodius and the coincidence may therefore not be significative.

The conflict between Adrastus and Amphiaraus is also related by the two texts. ${ }^{63}$ Asclepiades' account is preserved via the MH once again. The wording is very different in the two narratives, as its structure, for Apollodorus gives a very long account with many expansions or digressions, as already said. They follow essentially the same version. There are, however, minor divergences or omissions:

61 But again, the context of Asclepiades' quotation also provides the variant of punishment by deprivation of musical art.

62 Apollod. Bibl. 1.9.16 [107]; FGrH 12F31 (schol. Hom. Od. 12.69 Ernst).

63 Apollod. Bibl. 3.6.1-7.5 [58-87]; FGrH 12F29 (Schol. Hom. Od. 11.326-7 Ernst). 
the name of Amphiaraus' father differs slightly and Apollodorus' account of how Polyneices knows that he must offer the necklace to Euripyle is omitted by the MH's Asclepiades fragment. Apollodorus omits Alcmaeon's name. He refers to Amphiaraus' sons in general and the MH's Asclepiades also mentions the epigonoi. Apollodorus sets the episode of Alcmaeon's matricide and madness after the war of the epigonoi and duplicates the motives, making the son of Polyneices give Euripyle a present to obtain her support for the war against Thebes. ${ }^{64}$ Again, Apollodorus cannot have drawn on the MH's Asclepiades directly but we cannot exclude the possibility that both follow Asclepiades' original, at least partially.

The Epitome, as pointed out above, presents a different situation, as we do not have Apollodorus' text itself but a summary in two different recensions. Six thematic coincidences are found there.

Ixion's crime and punishment are related both in the Epitome and in an Asclepiadean fragment. ${ }^{65}$ However, the quotation of Asclepiades is corrupt and it is not possible to know for what detail or version he was quoted. ${ }^{66}$

Tantalos is a common figure, but the texts refer to different episode: the Epitome focuses on Tantalos' punishment in Hades while Asclepiades' fragment recounts his crime and consequent killing by Zeus, who crushes him with Mount Sipylon, not mentioned by Apollodorus. The only common detail is that both follow the same version of Tantalos' crime, relating that he stole ambrosia and delivered it to his people. This version of the crime was already known by Pindar. ${ }^{67}$

The Epitome gives two accounts of Neoptolemos' death, one of which follows the same version attributed to Asclepiades: he was killed by Machaireus at Delphi. But Apollodorus has information which is omitted by the Tragodoumena's fragment. This version on Neoptolemos' death was already known by Sophocles, according to another scholion. ${ }^{68}$

Asclepiades is quoted by a scholiast on Euripides for a variant in which Hermione had a son by Neoptolemos. This agrees with the Epitome's account that Neoptolemos took her when Orestes went insane. But they differ in that, according to the Bibliotheca, Hermione was already pregnant by Orestes in Troy.

Two accounts of Orestes' death are conveyed by the Epitome. ${ }^{69}$ One agrees with that found in an Asclepiadean fragment: both mention that he died in

64 Apollod. Bibl. 3.7 .5 [86]; FGrH 12F29 (Schol. Hom. Od. 11.326-7 Ernst).

65 Apollod. Epit. 1.20 - FGrH 12F3 (Schol. Pind. Pyth. 2.40ab Drachmann).

66 Villagra Hidalgo 2013.

67 Pind. Ol. 1.36-39.

68 TGF 4, Hyp. Hermione (Schol. Hom. Od. 4.1 = Eust. 1.141). Also attested by Str. 9.3.9.

69 Apollod. Epit. 6.30 - FGrH 12F25 (schol. Eur. Or. 1645 Schwartz). 
Arcadia from a snake bite. The only parallel to this is to be found in a scholion to Lycophron. ${ }^{70}$

Finally, the name of Hecabe's grave, 'the grave of the bitch', is mentioned by both the Epitome and a fragment transmitted by a scholion to Euripides. ${ }^{71}$ However, the name of the Chersonese promontory is known by many other sources and it already appears in Euripides. ${ }^{72}$

Genealogical information about the same figure is found eight times, of which two cases are divergences, ${ }^{73}$ three are full coincidences ${ }^{74}$ and the other three only partial coincidences ${ }^{75}$ - either the name of one of the parents differs, or is not refered by the words attributed to Asclepiades but by the context of the citation. The full agreements do not prove any direct relation since they are also attested in other sources.

If we take into account the intermediary sources of Asclepiades' fragments, we see that six thematic coincidences have been conveyed by Homeric scholia which are considered to belong to the $\mathrm{MH},{ }^{76}$ four by scholia to Euripides, ${ }^{77}$ four by scholia to Pindar ${ }^{78}$ and three by scholia to Apollonius Rhodius. ${ }^{79}$ The numeric superiority of the MH is too small to be significant. Furthermore, it is not possible to find a pattern between the intermediary source and the type of coincidence: in

70 Schol. Lycoph. 1374.

71 Apollod. Ep. 5.24 - FGrH 12F24 (schol. Eur. Hec. 1273 Schwartz).

72 Eur. Hec. 1257-1275; Str. 13.1.28, 7a.1.56; Ov. Met. 13.423-575; Hyg. Fab. 111; Serv. Aen 3.6.

73 On Orpheus: Apollod. Bibl. 1.9.16 [111] - FGrH 12F6; on Phineus: Apollod. Bibl. 1.9.21 [120] FGrH 12F22 (Schol. Ap. Rhod. 2.178-82ab Wendel).

74 On Glaucus: Apollod. Bibl. 1.9.3 [85] - FGrH 12F1; on Arsinoe: Apollod. Bibl. 3.10 .3 [118-119] FGrH 12F32 (Schol. Pind. Pyth. 3.14); on Pegasos: Apollod. Bil. 2.3.2 [32] - FGrH 12F13 (Schol. Hom. Il. 6.155 van Thiel).

75 On Jason's genealogy: Apollod. Bibl. 1.9.16 [107] - FGrH 12F31 (schol. Hom. Od. 12.69 Ernst); on Deucalion: Apollod. Bibl. 1.7.2 [46, 49]; F 26 = Schol. Hom. Od. 10.2; on Alastor: Apollod. Bibl. 1.9.9 [93]; FGrH 12F21 (schol. Ap. Rhod. 1.156-60b Wendel).

76 F26 (Schol. Hom. Od. 10.2) - Apollod. 1.7.2 [46, 49]; F31 (Schol. Hom. Od. 12.69), Apollod. Bibl. 1.9.16 [107]; 1.9.21 [120]; F14 (Schol. Hom. Il. 7.467 Van Thiel) - Apollod. 1.9.17-18 [114-15]; F12 (Schol. Il. 3.325 van Thiel) - Apollod. 3.4.2 [149]; F30 (Schol. Od. 11.582 Ernst) - Apollod. Ep. 1.24. 77 F25 (schol. Eur. Or. 1645 Schwartz) - Ep. 6.30; F24 (schol. Eur. Hec. 1273 Schwartz) - Apollod. Ep. 5.24; F10 (Schol. Eur. Rhes. 916 (Merro) - Apollod. Bibl. 1.3.3 [17]; F23 (Schol. Eur. Andr. 32 Schwartz) - Apollod. Ep. 6.13-14.

78 F3 (Schol. Pind. Pyth. 2.40ab Drachmann) - Ep. 1.20; F6a (Schol. Pind. Pyth. 4.313a) - Apollod. Bibl. 1.9.16 [111]; F 32 (Schol. Pind. Pyth. 3.14 Drachmann) - Apollod. 3.10.3 [118-119]; F15 (Schol. Pind. Nem. 7.62abc Drachmann) - Apollod. Ep. 6.14.

79 F21 (Schol. Ap. Rhod. 1.156-60b Wendel) - Apollod. Bibl. 1.9.9 [93]; F22 (Schol. Ap. Rhod. 2.178-82ab Wendel) - Apollod. Bibl. 1.9.21 [120]; F2 (Schol. Ap. Rhod. 2.328a + 2.562 Wendel) Apollod. Bibl. 1.9.22 [125]. 
all cases, there are detail coincidences that could be due to the use of a common source (i. e. Asclepiades), common subjects where the two texts follow different versions and also partial parallels. Of the six parallels with Asclepiades' fragments transmitted by the Homeric scholia-MH, only the narrative of Phineus' advice on navigating between the Symplegades and the mention of the name of the shepherd who raised Paris are positive parallels. Regarding the passages conveyed by the scholia to Euripides, the version of Orestes' death and the detail of the name of Hecabe's grave are common, but only Orestes' death may be significant.

The Asclepiadean fragments transmitted by the scholia to Pindar agree with the Bibliotheca on the version of Arsinoe's genealogy ${ }^{80}$ and on the name of Neoptolemos' killer, Machaireus. ${ }^{81}$ In the ones transmitted by the scholia to Apollonius Rhodius there is a parallel with Apollodorus in the fact that both mention Alastor $^{82}$ as a son of Neleus and both give the detail that the Argonauts navigated through the Symplegades with the aid of a dove. ${ }^{83}$

Divergences between Apollodorus and Asclepiades transmitted thorugh the Homeric scholia-MH relate to the stories of Jason's childhood, ${ }^{84}$ Phineus' punishment and liberation, ${ }^{85}$ the Lemnian androctony ${ }^{86}$ and Tantalos; ${ }^{87}$ in the scholia to Euripides, Tamyris' story differ from the Bibliotheca ${ }^{88}$ as do Orpheus' genealogy ${ }^{89}$ and the story on Ixion, ${ }^{90}$ and there is some divergence of detail in the accounts of the death of Neoptolemos ${ }^{91}$ in the scholia to Pindar and Apollodorus. In the scholia to Apollonius Rhodius, Phineus' genealogy is divergent. ${ }^{92}$

Therefore, when we compare the relationship between the Asclepidean fragments transmitted by the Homeric scholia-MH and the Bibliotheca, on the one hand, to the relationship of the Asclepiadean fragments transmitted by other intermediary sources and the Bibliotheca, on the other hand, it is not possible to set out any particularity in the fragments conveyed by the $\mathrm{MH}$. The fact that

80 F31.

81 F15.

82 F22.

83 F2.

84 F31.

85 F31.

86 F14.

87 F29.

88 F10.

89 F6.

90 F3.

91 F15.

92 F22. 
the MH's Asclepiades is the most frequent intermediary source for accounts that are found both in Apollodorus and Asclepiades of Tragilos could be caused by the fact that out of the 32 Asclepiadean fragments edited by Jacoby, nine are conveyed by scholia to Homer that are considered $\mathrm{MH}$, making it the most frequent intermediary source of Asclepiadean fragments.

\section{Conclusions}

The evidence to support the notion that the Tragodoumena was used by Apollodorus as a source of tragic plots is very limited. Nor do we have strong evidence that Apollodorus drew on the Tragodoumena mainly through the MH. The main conclusion of this article is that the comparison between texts and textual artefacts proves useful when applied to a specific detail or myth, but this allows no room for generalisations. The frequency of positive coincidences is not sufficient to suggest global dependence. The present state of the texts precludes any definitive conclusion because when we have a fragmentary text we can never rule out the possibility that it is not representative of the original. Even when we can say that Apollodorus most probably depended on Asclepiades - for the Sphinx's riddle, for instance - we have no means to check if this dependence was at first- or second-hand. Many subjects are common to several texts, but Apollodorus' Bibliotheca is a comprehensive narrative from the beginning to the Trojan war. It is thus natural that he deals with many of the subjects we will find in scholia, theatre or poetry. On the other hand, neither the coincidences nor the oppositions are radical; most remain in a grey fog of partial similarities. As a consequence, one wonders if the fact that the texts share thematic or structural narrative features is not simply the effect of a common cultural ambiance. Regarding the Tragodoumena and the Tales from Euripides, I think that they have been channelled by different traditions, which would suggest a different nature in their origin.

Finally, I believe that this exercise proves useful in highlighting many methodological issues that come up when we endeavour this type of work: besides the aforementioned problem of comparing a text to a textual artefact, we need to think about what to compare - details, narrative structure, subject, wording and how we should interpret the data, as many coincidences are partial. 


\section{Bibliography}

Alganza Roldán, Minverva. La mitografía como género de la prosa helenística, Florllib 17 (2006), 9-37.

Asirvatham, Sulochana R. Asklepiades of Tragilos (12), in: Brill's New Jacoby, edited by lan Worthington (Brill online, 2014).

Barrett, W.S. The Epitome of Euripides' Phoinissai: Ancient and Medieval Versions: I. The Three Versions. CQ 15 (1965), 58-70.

Barrett, W.S. (ed.) Euripides: Hippolytus (Oxford: Clarendon, 1964).

Bethe, Erich. Questiones Diodoreae mythographae (Diss. Göttingen, 1887).

Bond, Godfrey W. Euripides: Heracles with Introduction and Commentary (Oxford: Clarendon Press, 1981).

Cameron, Alan. Greek Mythography in the Roman World (New York: Oxford University Press, 2004).

Cuartero, Francesc J. Pseudo-Apol·lodor. Biblioteca. Vol. 1 [Llibre primer] (Barcelona: Fundació Bernat Metge, 2010).

Cuartero, Francesc J. Pseudo-Apol·lodor. Biblioteca. Vol. 3 [Llibre tercer] (Barcelona: Fundació Bernat Metge, forthcoming).

Diggle James. Euripidis Fabulae (Oxford: Oxford University Press, 1989).

Fowler, Robert L. Early Greek Mythography. Volume I: Texts and Introduction (Oxford: University Press, 2000).

Fowler, Robert L. How to Tell a Myth: Genealogy, Mythology, Mythography. Kernos 19 (2006), 35-46.

Fowler, Robert L. 2013. Early Greek Mythography. Volume II: Commentary (Oxford: University Press, 2000).

Frade, Sofia. Heracles and Athenian Propaganda: Politics, Imagery and Drama (London, forthcoming).

Fraser, Peter M. and Elaine Matthews (ed.). Lexicon of Greek Personal Names IV: Macedonia, Thrace, Northern Regions of the Black Sea (Oxford: Clarendon, 2005).

Haslam, Michael S. The Authenticity of Euripides' Phoenissae 1-2 and Sophocles' Electra 1. GRBS 16 (1975), 149-174.

Higbie, Carolyn. Hellenistic Mythographers, in: The Cambridge Companion to Greek Mythology, edited by R.D. Woodard (Cambridge: University Press, 2007), 237-254.

Huys, Marc. Euripides and the Tales from Euripides: Sources of Apollodorus' Bibliotheca? Rh. Mus. 140 (1997), 308-327.

Jacoby, Felix. Die Fragmente der griechischen Historiker. Erster Teil. Genealogie und Mythographie. Kommentar. Nachträge (Leiden: Brill, 1957; 1923¹).

Jouan, François and Herman van Looy. Euripidie. Tragédies. Tome VIII Part 3: Fragments de Bellérophon à Protésilas (Paris: Belles Lettres, 2000).

Katz, Joshua T. The Riddle of the Sp(h)ij-: The Greek Sphinx and her Indic and Indo-European Background. Princeton/Stanford Working Papers in Classics (2005), 2-30.

Kenens, Ulrike. The Sources of Ps.-Apollodorus's Library: A Case-Study. Quaderni Urbinati di Cultura Classica 97 (2011), 129-146.

Mastronarde, Donald J. Euripides: Phoenissae (Cambridge: University Press, 1994).

Meccariello, Chiara. Le hypotheseis dei drammi Euripidei (Roma: Edizioni di Storia e Letteratura, 2014). 
Meliadò, Claudio. Mythography, in: Brill's Companion to Ancient Greek Scholarship, edited by F. Montanari, S. Matthaios and A. Rengakos (Leiden: Brill, 2015), 1057-1089.

Montanari, Franco. Filologia omerica antica nei papiri, in: Proceedings of the XVIII Congress of Papyrology, Athens, 25-31 May 1986 vol. II, edited by Vasileios G. Mandēlaras (Athens: Greek Papyrological Society, 1988), 337-344 (= F. Montanari, Studi di Filologia Omerica Antica II (Pisa: Giardini, 1995), 69-85).

Müller, Carl \& Müller, Theodor. Fragmenta Historicorum Graecorum. Vol. III (Paris: Didot, 1849).

Osborne, M.J. and S.G. Byrne (eds.). Lexicon of Greek Personal Names II: Attica (Oxford: University Press, 1994).

Pagès, Joan. Mythographus Homericus. Estudi i edició comentada (Diss. Universitat Autònoma de Barcelona, 2007).

Pàmias, Jordi. (ed.). Ferecides d'Atenes, Històries. Fragments 81-180A. Introducció, edició crítica, traducció i notes, Vol. II (Barcelona: Fundació Bernat Metge, 2008).

Panzer, Johannes. De Mythographo Homerico restituendo (Diss. Greifswald, 1892).

Pellizer, Ezio. La mitografia, in: Lo spazio letterario della Grecia antica, Vol. I. La produzion e la circolazione del testo, tomo II. L'ellenismo, edited by G. Cambiano et al. (Roma: Salerno, 1993), 283-303.

Robert, Carl. De Apollodori Bibliotheca (Diss. Berlin: Schade, 1873).

Robert, Carl. Oedipus. Geschichte eines poetischen Stoffs im griechischen Altertum (Berlin: Weidmann, 1915).

Rusten, Jeffrey. Dicaearchus and the Tales from Euripides. GBRS 23 (1982), 357-367.

Schwartz, Jacques. Papyrus et tradition manuscrite, ZPE 4 (1969), 175-182.

Turner, Eric G. 2459. Euripides, Oedipus, in: The Oxyrhynchus Papyri 27 (1962), 81-86.

Van Rossum-Steenbeek, Monique. Greek Reader's Digests? Studies on a selection of subliterary papyri (Leiden-New York-Köln: Brill, 1998).

Villagra Hidalgo, Nereida. Pègasos i el fragment 13 d'Asclepíades de Tràgilos, in: Artes ad Humanitatem vol. I, edited by E. Borrell and P. Gómez (Barcelona: SEEC, 2010), 177-185.

Villagra Hidalgo, Nereida. Commenting on Asclepiades of Tragilos: Methodological Considerations on a Fragmentary Mythographer, in: Learning from the Past: Methodological Considerations on Studies of Antiquity and Middle Ages. Proceedings of the First Postgraduate Conference on Studies of Antiquity and Middle Ages, edited by A. Castro et al. British Archaeological Reports International Series (Oxford, 2013), 289-296.

Villagra Hidalgo, Nereida. Fragmentary Mythography as a Source: Neoptolemos at Delphi in the Tragodumena, in: Actes du Colloque International "Quelles sources pour l'étude de la Méditerranée antique: approches, enjeux, méthodes (8, 9 d'avril, 2011)”, edited by Mathilde Carrive, Marie-Adeline Le Guennec and Lucia Rossi (Aix-en-Provence: Presses Universitaires de Provence, 2014), 27-41.

Werfer, F. X. Asclepiadis Tragilensis Tragodoumenôn reliquiae, Acta Philologorum Monacensium 2 (1815), 491-557.

Zuntz, Günther. The Political Plays of Euripides (Manchester: University Press, 1955). 